\title{
Gill tissues of the mussel Mytilus edulis chilensis: A new source for antimicrobial peptides
}

\author{
Luis Mercado* \\ Laboratorio de Genética e Inmunología Molecular \\ Instituto de Biología \\ Pontificia Universidad Católica de Valparaíso \\ Av. Brasil 2950, Valparaíso, Chile \\ Tel: 5632273117 \\ Fax: 5632596703 \\ E-mail:1mercado@ucv.cl \\ Paulina Schmitt \\ Laboratorio de Genética e Inmunología Molecular \\ Instituto de Biología \\ Pontificia Universidad Católica de Valparaíso \\ Av. Brasil 2950, Valparaíso, Chile \\ Tel: 5632273117 \\ Fax: 5632596703 \\ E-mail: paulina.schmitt@ucv.cl \\ Sergio H. Marshall \\ Laboratorio de Genética e Inmunología Molecular \\ Instituto de Biología \\ Pontificia Universidad Católica de Valparaíso \\ Av. Brasil 2950, Valparaíso, Chile \\ Tel: 5632273119 \\ Fax: 5632596703 \\ E-mail:smarshal@ucv.cl

\section{Gloria Arenas} \\ Laboratorio de Genética e Inmunología Molecular \\ Instituto de Biología \\ Pontificia Universidad Católica de Valparaíso \\ Av. Brasil 2950, Valparaíso, Chile \\ Tel: 5632273117 \\ Fax: 5632596703 \\ E-mail: garenas@ucv.cl
}

Financial support: INCO-DEV: IMMUNAQUA ICA4-CT-2001-10023 and DI-PUCV 122.779/2004.

Keywords: antimicrobial peptides, biochemical characterization, gill tissues, in vitro activity, mussels.

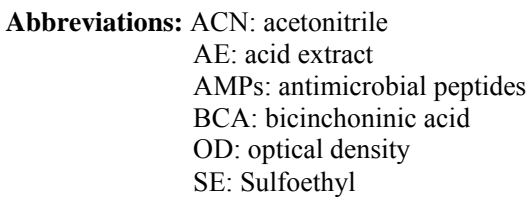

Abbreviations: ACN: acetonitrile

AE: acid extract

AMPs: antimicrobial peptides

BCA: bicinchoninic acid

OD: optical density

SE: Sulfoethyl

Antimicrobial peptides are small-sized, cationic and amphipathic molecules able to neutralize pathogenic microorganisms. Their antimicrobial effects tie them to mechanisms of immune defense, which is why they have been normally purified from immune cells. We describe an apparently new group of antimicrobial peptides from gill tissues of the mussel Mytilus edulis chilensis. 20 specimens yielded $40 \mathrm{~g}$ of gills which produced $16 \mathrm{mg}$ of an enriched fraction with antimicrobial activity as low as $0.045 \mu \mathrm{g} / \mu \mathrm{l}$ over reference strains. Considering the chemical nature of these molecules we used an acid extraction procedure followed by consecutive cationic exchange and hydrophobic interaction chromatography steps for peptide enrichment. The resulting post Seppak C-18 ${ }^{\circledR} \quad 20 \%$ acetonitrile (ACN) eluate was fractionated by reverse phase HPLC and all resulting fractions were the source for in vitro antimicrobial activity evaluation. Active fractions were characterized by SDS-containing protein gel electrophoresis. All fractions were particularly enriched with low molecular

\footnotetext{
* Corresponding author
} 
weight peptides displaying neutralizing growth activity against Gram positive and Gram negative bacteria and 10 times more efficient over fungal pathogens. Active fractions resulted to be thermostable and non cytotoxic to eukaryotic cells. Considering these results, industrial waste gills of bivalves arise as a new source for antimicrobial molecules.

Antimicrobial peptides (AMPs) - also known as host defense peptides (HDP) are ubiquitous molecules involved in natural defense mechanisms against pathogens. They are widely distributed in animal and plant kingdoms suggesting their participation in the evolutionary success of target organisms (Zasloff, 2002). These molecules have been investigated for at least the last four decades, resulting up to the description of over a thousand of AMPs (http://www.bbcm.univ.trieste.it/ tossi/antimic.html; http://aps.unmc.edu/AP/main.php).

In invertebrates, AMPs are recognized as important components of innate immunity. They are usually low molecular weight molecules, among 12 and 45 amino acids in length, with $\beta$-folded or $\alpha$ - structure, cationic and amphipathic (Bulet et al. 2004). Although recent studies show that some of the peptides may have intracellular targets (Cudic and Otvos, 2002), the vast majority appear to act by permeabilization of the bacterial cell membrane (Yeaman and Yount, 2003). Some kind of peptides have disulfide bridges that determine the secondary structure, making them suitable for its antimicrobial action (Hancock and Diamond, 2000; Marshall and Arenas, 2003). In marine invertebrates, Mytilus galloprovincialis and Mytilus edulis have been the most studied (Tincu and Taylor, 2004); particularly the hemocytes, where almost all AMPs described belong to the defensin family (Charlet et al. 1996; Mitta et al. 1999a; Mitta et al. 1999b). On the other hand, epithelial tissues, as one of the first physical barrier encounter by any pathogen, have been also the centre of attention in the search for new AMPs (Iijima et al. 2003). The same has been shown for insects with the demonstration of specific AMP mRNA expression in epithelial cells (Ferrandon et al. 1998), strengthening the idea that these tissues are predominant reservoirs functioning in local defence against pathogenic microorganisms. As an example and centring on marine environments, branchial, intestinal, and epidermal tissues of fish have provided a great variety of these molecules (Richards et al. 2001; Lauth et al. 2002; Iijima et al. 2003). In bivalves, the same has been achieved for mussels (Haug et al. 2004), turning epithelial cells from the Chilean native mussel Mytilus edulis chilensis into a target model to screen for new and ideally novel AMPs for biotechnological purposes (Marshall and Arenas, 2003). In this report we describe an efficient recovery of at least one putatively new cationic and amphipatic AMP species displaying a broad antimicrobial range and high specific activity, thus suitable for biotechnological processing.

\section{MATERIALS AND METHODS}

\section{Mussels and gills collection}

Live specimens of Mytilus edulis chilensis were obtained commercially from Puerto Montt, Chile. Mussels were kept on ice until gill tissue isolation and once filaments were dissected and dried with Watman $3 \mathrm{M}$ paper, they were stored at $-80^{\circ} \mathrm{C}$ until use.

\section{Processing gills}

The purification procedure is summarized as follows. Frozen gills from 20 specimens were crushed to homogeneity in liquid nitrogen. The resulting gill powder $(40 \mathrm{~g})$ was suspended in cold acetic acid $11 \%(1: 10)$, in order to solubilize cationic molecules, followed by vortexmixing for $5 \mathrm{~min}$. The homogenate was sonicated for $3 \times 30$ $\mathrm{sec}$ at 11 resonant macrosonic synthesis (RMS) in ice and incubated with mild agitation at $4^{\circ} \mathrm{C}$ overnight. The crude extract was centrifuged at $11,000 \mathrm{x} \mathrm{g}, 35 \mathrm{~min}$ at $4^{\circ} \mathrm{C}$ and the pellet was discarded. The supernatant was called acid extract (AE) and further shaken at $37^{\circ} \mathrm{C}$ for $1 \mathrm{hr}$ to favour sugar hydrolysis. Tris-base crystals were slowly added to raise the $\mathrm{pH}$ to a value of 3.0. In order to enrich cationic peptides, four batches of $100 \mathrm{ml}$ each of $\mathrm{AE}$ were sequentially mixed overnight with a Sulfoethyl (SE) Sephadex C-50 cation-exchange beads (BioRad) with mild agitation at $4^{\circ} \mathrm{C}$ in a ratio of $1,5 \mathrm{ml}$ gel slurry $/ 25 \mathrm{ml} \mathrm{AE}$. The mixture was centrifuged at $1,500 \times \mathrm{g} 10 \mathrm{~min}$ and resuspended in $1 \%$ acetic acid $0.1 \mathrm{M} \mathrm{NaCl}(\mathrm{pH} \mathrm{3.0)}$.

Table 1. Total protein concentration on each resulting fraction from the purification procedure.

\begin{tabular}{|c|c|c|c|c|}
\hline Samples & {$[\mathrm{mg} / \mathrm{ml}]$} & V (ml) & Total protein [mg] & $\%$ From initial \\
\hline \multicolumn{5}{|c|}{ Purified gills (40 g) } \\
\hline Acid Extract & 3.36 & 400.0 & $1,346.40$ & ----- \\
\hline \multicolumn{5}{|c|}{ Eluted Sep-pak C-18 $®$} \\
\hline $5 \% \mathrm{ACN}$ & 0.88 & 0.4 & 0.35 & 0.02 \\
\hline $20 \% \mathrm{CAN}^{*}$ & 40.00 & 0.4 & 16.00 & 1.18 \\
\hline $60 \%$ ACN & 3.56 & 0.4 & 1.42 & 0.10 \\
\hline $80 \% \mathrm{ACN}$ & 0.625 & 0.4 & 0.25 & 0.18 \\
\hline
\end{tabular}

*The $20 \%$ ACN fraction was further processed through RP-HPLC. 
Putative peptides were recovered from beads with mild agitation for $1 \mathrm{hr}$ in the presence of $1 \%$ acetic acid $1 \mathrm{M}$ $\mathrm{NaCl}(\mathrm{pH} \mathrm{3.0})$. The eluate $(6 \mathrm{ml})$ was applied onto a Seppak C18 Vac cartridge (Waters Associates) equilibrated in acidified water $(0.05 \%$ trifluoroacetic acid in UPW-Ultra Pure Water). After a wash with acidified water, the peptides were eluted, flow $1 \mathrm{ml} / \mathrm{min}$, with $5 \%, 20 \%, 40 \%, 60 \%$ and $80 \%$ ACN, to obtain several hydrophobic fractions. The samples obtained were lyophilized and reconstituted in 200 $\mu l$ of UPW, total protein content determined by the BCA microplate assay (Pierce) and tested for antibacterial activity.

\section{HPLC purification}

All HPLC purification steps were performed on a RPHPLC model LaChrom D-7000 with a LaChrom model L7455 photodiode array detector. Column effluent was monitored by UV absorption at $225 \mathrm{~nm}$. Only the $20 \%$ Seppak eluates were selected for further purification and loaded on a Sephasil C-18 (250 x $4.1 \mathrm{~mm})$ column (LiChroCART). Elution was performed with a linear gradient of 5-60\% $\mathrm{ACN}$ in acidified water over $90 \mathrm{~min}$ at a flow rate of $0.6 \mathrm{ml}$ $\mathrm{x} \mathrm{min}^{-1}$. The resulting fractions were collected every two minutes, lyophilized, reconstituted in UPW and frozen at $20^{\circ} \mathrm{C}$ until antimicrobial activity testing.

\section{Reference pathogenic strains and growth conditions}

Micrococcus luteus (ATCC 4698) and Staphylococcus epidermidis (ATCC 49461) were used as reference Grampositive bacteria; Escherichia coli (ATCC 11303) and Aeromona hydrophila (ATCC 23213) as Gram-negative; while filamentous fungi were represented by Fusarium oxysporum and Neurospora crassa, kindly provided by Dr E. Bachère from Université Montpellier-2, France. The aquatic fungi Saprolegnia sp. was a generous gift from Dr. Piontelli - Universidad de Valparaíso, Chile. All bacteria were grown at $37^{\circ} \mathrm{C}$ in Trypticase Soy Broth (TSB, Difco), $F$. oxysporum and $N$. crassa were grown at room temperature in Potato Dextrose Broth (PDB, Difco) and Saprolegnia sp. was grown in Glucose Yeast (GY) broth. All fungal spores were harvested as described previously (Broekaert et al. 1990).

\section{Antimicrobial activity assay}

Antibacterial activity of all resulting fractions was determined by the microplate assay described by Mitta et al. (1999). M. luteus, A. hydrophila, S. epidermidis and E. coli were incubated at $37^{\circ} \mathrm{C}$ in TSB until reaching an optical density (OD) $0.2-0.3$ at $620 \mathrm{~nm}$. Antibacterial activity was determined by incubating standard aliquots of $100 \mu \mathrm{l}$ of a $1 / 100$ dilution of the bacterial solution in triplicates, exposed to $10 \mu \mathrm{l}$ of target peptides. After $24 \mathrm{hrs}$ incubation at $37^{\circ} \mathrm{C}$, absorbance values at $620 \mathrm{~nm}$ were determined. Percentage growth inhibition was determined by subtracting bacterial growth values in the absence of peptides from that displayed by bacteria exposed to different concentrations of the target molecules. As a positive control for growth inhibition comercial cecropin P1a (SIGMA), was used at a concentration of $0.01 \mu \mathrm{g} / \mu 1$ amount known to fully inhibit Gram negative bacterial growth.

Antifungal activity was monitored against $F$. oxysporum, $N$. crassa and Saprolegnia sp. by a liquid growth inhibition assay, as described by Fehlbaum et al.(1994) with minor changes. In summary, $80 \mu \mathrm{l}$ of fungal spores to a final concentration of $10^{4}$ spores $\mathrm{x} \mathrm{ml}^{-1}$, were added to $20 \mu \mathrm{l}$ of peptide solution on microtiter plates in the presence of tetracycline $(10 \mu \mathrm{g} / \mathrm{ml})$ and streptomycine $(10 \mu \mathrm{g} / \mathrm{ml})$, followed by $30 \mathrm{~min}$ incubation at room temperature after which absorbance at $595 \mathrm{~nm}$ was determined. The plates were further incubated under light at room temperature for another $72 \mathrm{hrs}$ and final OD values at 595 determined. Growth inhibition was established by subtracting fungal growth values at $72.5 \mathrm{hrs}$ in the absence of peptides from that displayed by fungal spores exposed to different concentrations of the target molecules.
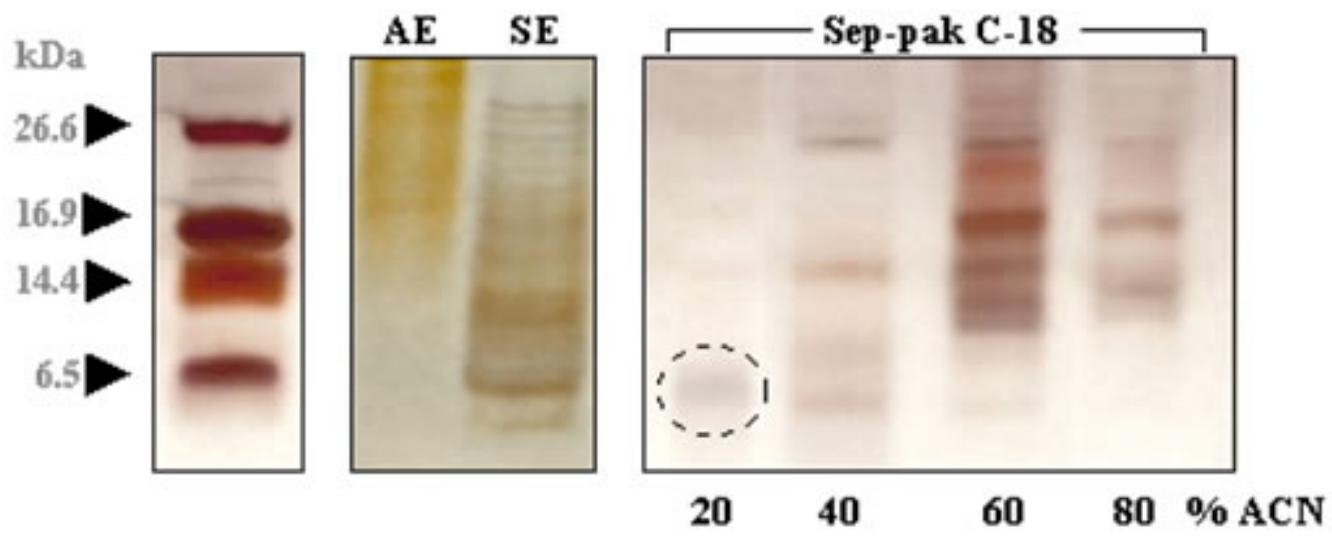

Figure 1. Electrophoretic profiles of low molecular weight enrichment of AMPs during gill processing. Identical concentration aliquots resolved through 18\% Tris-ricine SDS/PAGE. Silver Nitrate stained gels. AE, acid extract; SE, sulpho-ethyl Sephadex elution; Sep-pak C-18; differential elution fractions. 


\section{Cytotoxicity assay}

The effect of active fractions over the viability of eukaryotic cells was measured by exposing an established Chinook salmon embryo cells (CHSE-214) according standard procedures developed in our laboratory. Briefly, cell monolayers at $70 \%$ semiconfluency were washed with PBS and then the peptides added at a concentration of 1.5 $\mu \mathrm{g} / \mu \mathrm{l}$ per triplicate wells and incubated for the maximum viability time ( $3 \mathrm{hrs})$ without culture medium. Samples were then washed 3 times with excess PBS before adding $0.1 \%$ trypsin to release cells from the monolayer. Individual cell viability was determined using the Trypan Blue exclusion technique (Lee et al. 2002).

\section{Heat treatment}

The $20 \%$ ACN peptide-enriched fraction was tested for heat sensitivity. Two parallel samples were treated either at $50^{\circ} \mathrm{C}$ or $100^{\circ} \mathrm{C}$ for 30 and $60 \mathrm{~min}$, respectively. Immediately thereafter, their antibacterial activity was tested against $M$. luteus using non-heated samples as controls.

\section{Electrophoresis}

To estimate low molecular weight peptide sizes, $18 \%$ denaturanting SDS-PAGE, polyacrylamide tris-tricine-urea gel electrophoresis was employed (Schagger and von Jagow, 1987). In order to calculate relative molecular weights, Polypeptide SDS-PAGE commercial standard marker was used (BioRad). Gels were stained either with Coomassie brilliant blue and/or Silver Nitrate kits (Winkler) depending on protein concentration in samples.

Table 2. Citotoxicity assay of the $20 \% \mathrm{ACN}$ fraction and post RP-HPLC active fractions over CHSE-214 cells.

\begin{tabular}{|l|c|}
\hline Samples assayed for cytotoxicity & \% viability \\
\hline $20 \%$ ACN & 77.9 \\
\hline post HPLC & 73.0 \\
\hline $\mathrm{fx} 19$ & 82.1 \\
\hline $\mathrm{fx} 20$ & 84.4 \\
\hline $\mathrm{fx} 21$ & 86.6 \\
\hline $\mathrm{fx} 22$ & 77.2 \\
\hline Distilled water (blank) & \\
\hline
\end{tabular}

\section{RESULTS}

Table 1 shows a comparative protein concentration recovery from gill samples enriched in active AMPs throughout the process described in this report. From the selected enriched fraction (post RP-HPLC 20\% ACN) yield equals $1.18 \%$ of low molecular weight AMPs per $40 \mathrm{~g}$ of processed Mytilus edulis chilensis gills.

Figure 1 shows the polypeptide profiles throughout the processing procedure. Compared to AE, SE and post Seppak $20 \%$ and $40 \%$ ACN fractions are clearly enriched in low molecular weight peptides. Nonetheless, the content of the $20 \%$ fraction is particularly enriched in low molecular weight peptides. Although the $40 \%$ fraction is more heterogeneous but also seems enriched in these low molecular weight species, the specific activity of the former as well as their uniqueness drove us to favour their characterization.
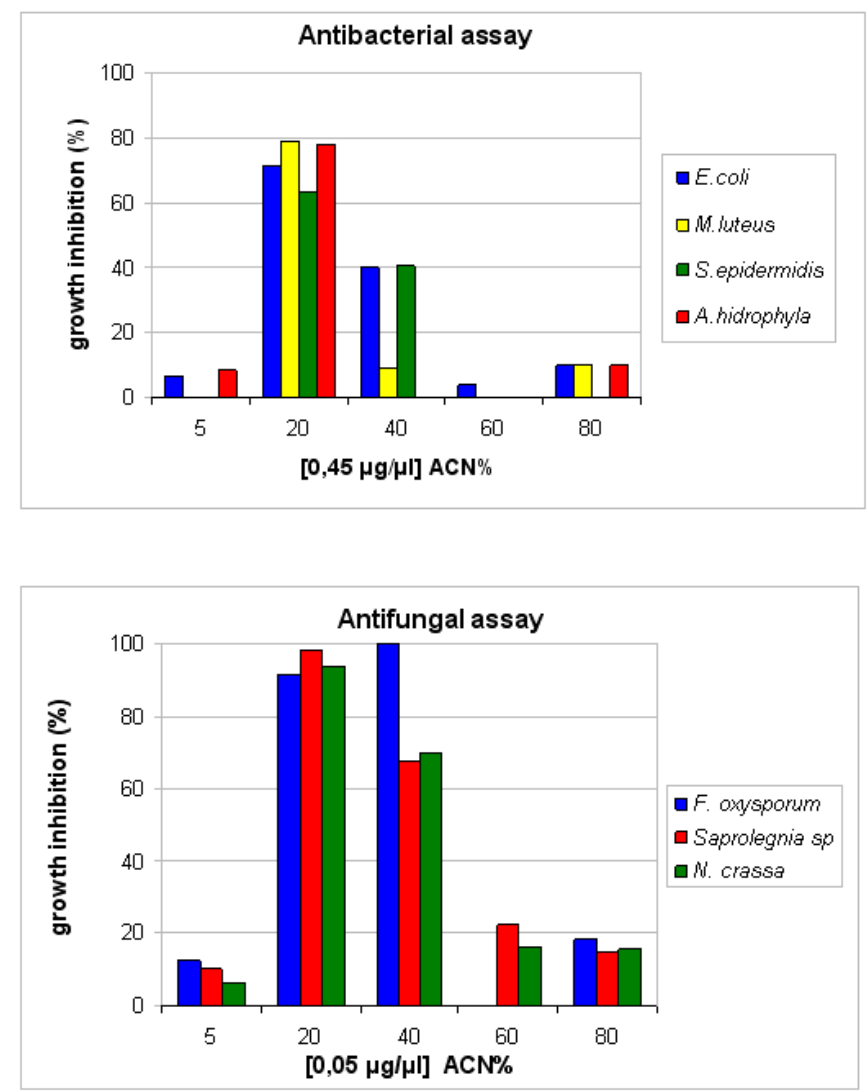

Figure 2. Antibacterial and antifungal activity of 5 to $80 \%$ ACN post Sep-pak eluates.

Figure 2 shows the results of all post Sep-Pak C-18 fractions tested for antimicrobial activity over standard strains of bacteria (G+ and G-) as well as over selected fungi strains. In general, testing required 10 higher concentrations for bacteria than for fungi. For bacteria, the $20 \%$ ACN fraction was the most efficient with a minimal growth inhibition of $65 \%$ although inhibition over $75 \%$ was obtained over M. luteus and A. hydrophila. For fungi, both fractions $20 \%$ and $40 \%$ ACN were equally efficient, also with a minimal growth inhibition of $65 \%$. Noticeably, inhibition reached over $90 \%$ for the $40 \%$ ACN fraction over Fusarium oxysporum, but the $20 \%$ ACN fraction was by all means more effective over most of the fungal strains tested reaching inhibition values close to $90 \%$.

In order to evaluate another physicochemical parameter associated with these novel molecules we determined if heat had any effect over the observed antimicrobial activity. Aliquots of the $20 \% \mathrm{ACN}$ fraction were heated at either $50^{\circ} \mathrm{C}$ or $100^{\circ} \mathrm{C}$ for 30 or $60 \mathrm{~min}$. Figure 3 shows that using $M$. luteus as a reference strain, the activity was not at all affected at a concentration of $0.45 \mu \mathrm{g} / \mu \mathrm{l}$. 


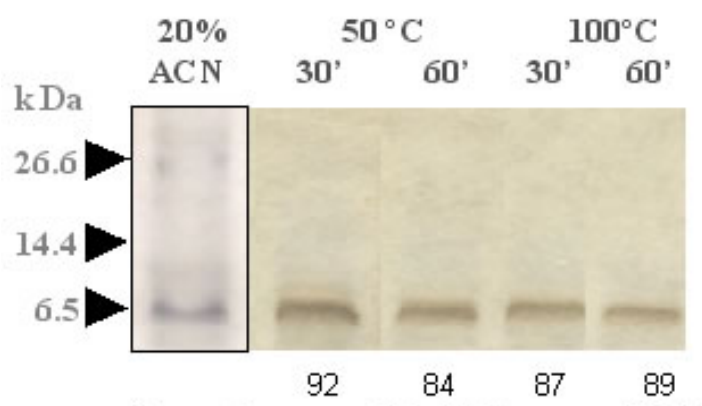

Percentage growth inhibition over $M$. luteus

Figure 3. Thermal effect over the structure and antimicrobial activity of the post-Sep-pak C-18 20\% ACN fraction. Tris Tricine 18\% SDS/PAGE.

Next, to further resolve the $20 \%$ ACN fraction, $300 \mu \mathrm{g}$ were loaded onto an RP-HPLC. Figure 4 shows all resulting fractions of which only numbers 19 to $22(12-15 \mu \mathrm{g}$ each) eluting between $26-30 \%$ ACN were active against $M$. luteus. Resolution through $18 \%$ tris-tricine SDS-PAGE (insert in Figure 4), confirms a clear enrichment in a low molecular weight band over the control.
Finally, in order to rule out cytotoxicity of the $20 \%$ post sep-pak eluate as well as the post RP-HPLC positive fractions, $1,5 \mu \mathrm{g} / \mu \mathrm{l}$ in distilled water of each, corresponding to three times the inhibitory concentration over the reference bacterial strain were exposed for $3 \mathrm{hrs}$ to the fish cell line CHSE-214 (Table 2). None of the fractions tested affected cell viability.

\section{DISCUSSION}

AMPs from marine invertebrates have been normally isolated from hemocytes (Patrzykat and Douglas, 2003). When reported for epithelial tissues it has been assumed that it was due to hemocyte infiltration (Mitta et al. 2000). Nonetheless, a recent report describes antimicrobial activity associated with crude extract from different tissues obtained from the mussel Modiolus modiolus (Haug et al. 2004), although the activity was not linked to low molecular weight molecules. In this report the amount of peptides recovered from isolated gills suggest that most likely gills, and perhaps other epithelial tissues, naturally express endogenous AMPs. Mussel hemocytes AMPs are normally isolated after an acid extraction step followed by a Sep-pak column enrichment in which peptides are eluted

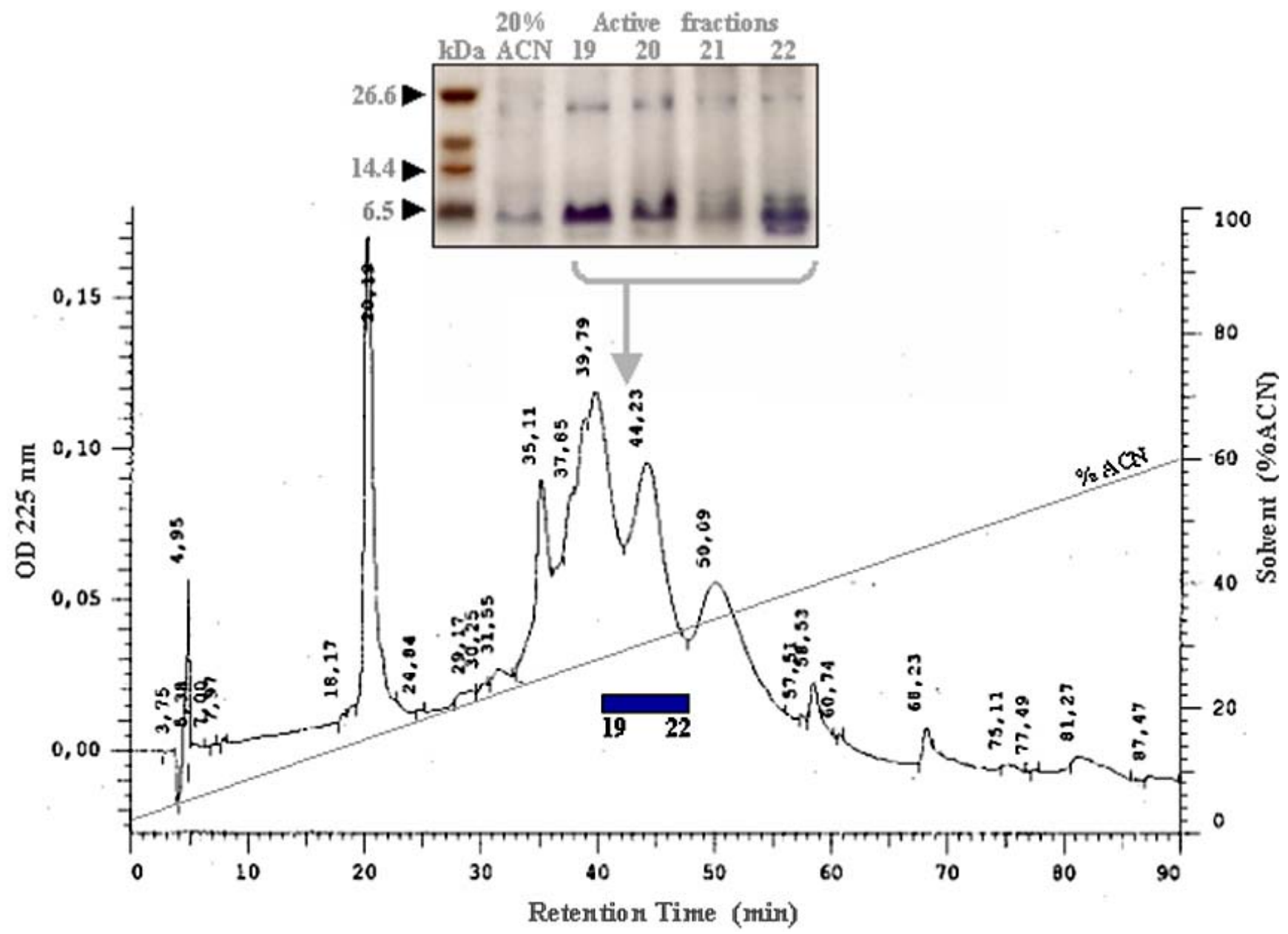

Figure 4. RP-HPLC elution profile of the $20 \%$ ACN post Sep-pak C-18 with a gradient of $5-60 \%$ ACN in $0.05 \%$ TFA. Bar: active fractions. Insert: Tris-Tricine $18 \%$ SDS-PAGE characterization of active fractions. 
with step gradients of $5-40-80 \% \mathrm{ACN}$, and active peptides are mostly recovered in the $40 \%$ fraction. For gills, the step gradient elution procedure was widened including two additional steps of 20 and $60 \%$ ACN. Although gills also provided a $40 \%$ AMP rich fraction, we found an as yet unreported noticeably antimicrobial activity in the $20 \%$ ACN elution fraction. These results suggest that this fraction is enriched in a less hydrophobic thermostable distinct class of active AMPs which displays a powerful action over fungi as well as both Gram - and Gram + bacteria. Thus, we decided to further characterize the novel $20 \%$ ACN fraction through RP-HPLC recovering active molecules using a linear $5-60 \%$ ACN elution gradient. Out of 45 total fractions, active AMPs eluted in four distinct fractions between 26 and $30 \%$ ACN devoided of cell cytotoxicity.

Based upon our results and considering that mussel gills represent roughly $13 \%$ of the smooth body weight portion, we consider this tissue as a reasonable source for new antimicrobial molecules. If this is the case, this approach could be extended in the future to other tissues, especially to those involving tissues discarded in the industrial processing of commercial marine invertebrates. Thus, we have demonstrated in this report that adding a slight modifications to existing protocols broadened the range of extractable AMPs resulting in high specific activity new species in the $20 \% \mathrm{ACN}$ fraction. Additionally we have foresee a potential use for byproducts in the aquaculture industry as a source for new pharmaceutical molecules. We are in the process of designing strategies to prove the feasibility of these alternatives.

\section{REFERENCES}

BROEKAERT, Willem; TERRAS, Franky R.G.; CAMMUE, Bruno P.A. and VANDERLEYDEN, Jozef. An automated quantitative assay for fungal growth inhibition. FEMS Microbiology Letters, May 1990, vol. 69, no. 1-2, p. 55-60.

BULET, Philippe; STOCKLIN, Reto and MENIN, Laure. Anti-microbial peptides: from invertebrate to vertebrate. Immunological Reviews, April 2004, vol. 198,no. 1, p.169184.

CHARLET, Maurice; CHERNYSH, Serguey; PHILIPPE, Hervé; HETRU, Charles; HOFFMANN, Jules A. and BULET, Philippe. Innate Immunity. Isolation of several cysteine-rich antimicrobial peptides from the blood of a mollusc, Mytilus edulis. The Journal of Biological Chemistry, September 1996, vol. 271, no. 36, p. 2180821813.

CUDIC, Mare and OTVOS Laszlo Jr. Intracellular targets of antibacterial peptides. Current Drug Targets, April 2002, vol. 3, no. 2, p. 101-106.
FEHLBAUM, Pascale; BULET, Philippe; MICHAUT, Lydia; LAGUEUX, Marce; BOEKAERT, Willem F.; HETRU, Charles and HOFFMANN, Jules A. Insect immunity. septic injury of Drosophila induces the synthesis of a potent antifungal peptide with sequence homology to plant antifungal peptides. The Journal of Biological Chemistry, December 1994, vol. 269, no. 52, p. 3315933163.

FERRANDON, Dominique; JUNG, A.C.; CRIQUI, M.; LEMAITRE, B.; UTTENWEILER-JOSEPH, S.; MICHAUT, L.; REICHHART, J.; and HOFFMANN, J.A. A drosomycin-GFP reporter transgene reveals a local immune response in Drosophila that is not dependent on the Toll pathway. EMBO Journal, August 1998, vol. 17, no. 5 , p. 1217-1227.

HANCOCK, Robert and DIAMOND, Gill. The role of cationic antimicrobial peptides in innate host defences. Trends in Microbiology, September 2000, vol. 8, no. 9, p. 402-410.

HAUG, Tor; STENSVAG, Klara; OLSEN, M Organ M.; SANDSDALEN, Erling and STYRVOLD, Olaf B. Antibacterial activities in various tissues of the horse mussel, Modiolus modiolus. Journal of Invertebrate Pathology, February 2004, vol. 85, no. 2, p. 112-119.

IIJIMA, Noriaki; TANIMOTO, Norio; EMOTO, Yohko; MORITA, Yohko; UEMATSU, Kazumasa; MURAKAMI, Tomoya and NAKAI, Toshihiro. Purification and characterization of three isoforms of chrysophsin, a novel antimicrobial peptide in the gills of the red sea bream, Chrysophrys major. European Journal of Biochemistry, February 2003, vol. 270, no. 4, p. 675-686.

LAUTH, Xavier; SHIKE, Hiroko; BURNS, Jane C.; WESTERMAN, Mark E.; OSTLAND, Vaughn E.; CARLBERG, James M.; VAN OLST, Jon C.; NIZET, Victor; TAYLOR, Steven W.; SHIMIZU, Chisato and BULET, Philippe. Discovery and characterization of two isoforms of moronecidin, a novel antimicrobial peptide from hybrid striped bass. The Journal of Biological Chemistry, February 2002, vol. 277, no. 7, p. 5030-5039.

LEE, Jong-Hee; AHN, Sun-Hee; KIM, Sun-Hoi; CHOI, Yoon-Hyeok; PARK, Kee-Jai and KONG, In-Soo. Characterization of Vibrio mimicus phospholipase A (PhlA) and cytotoxicity on fish cell. Biochemical and Biophysical Research Communications, October 2002, vol. 298, no. 2, p. 269-276.

MARSHALL, Sergio $H$. and ARENAS, Gloria. Antimicrobial peptides: A natural alternative to chemical antibiotics and a potential for applied biotechnology. Electronic Journal of Biotechnology [online]. 15 December 2003, vol. 6, no. 3 [cited 6 June 2005]. Available from 
Internet:

http://www.ejbiotechnology.info/content/vol6/issue3/full/1/ index.html. ISSN 0717-3458.

MITTA, Guillaume; VANDENBULCKE, Franck; NOEL, Thierry; ROMESTAND Bernard; BEAUVILLAIN, Jean Claude; SALZET, Michel and ROCH, Philippe. Differential distribution and defence involvement of antimicrobial peptides in mussel. Journal of Cell Science, August 2000, vol. 113, part 15, p. 2759-2769.

MITTA, Guillaume; HUBERT, Florence; NOEL, Thierry and $\mathrm{ROCH}$, Philippe. Myticin, a novel cysteine-rich antimicrobial peptide isolated from haemocytes and plasma of the mussel Mytilus galloprovincialis. European Journal of Biochemistry, October 1999a, vol. 265, no. 1, p. 71-78.

MITTA, Guillaume; VANDENBULCKE, Franck; HUBERT, Florence and ROCH, Philippe. Mussel defensins are synthesised and processed in granulocytes then released into the plasma after bacterial challenge. Journal of Cell Science, December 1999b, vol. 112, no. 23, p. 4233-4242.

PATRZYKAT, Aleksander and DOUGLAS, Susan. Gone gene fishing: how to catch novel marine antimicrobials. Trends in Biotechnology, August 2003, vol. 21 no. 8, p. 362-369.

RICHARDS, Robert C.; O'NEIL, David B.; THIBAULT, Pierre and EWART, K. Vanya. Histone H1: an antimicrobial protein of Atlantic salmon (Salmo salar). Biochemical and Biophysical Research Communications, June 2001, vol. 284, no. 3, p. 549-555.

SCHAGGER, Hermann and VON JAGOW, G. Tricinesodium dodecyl sulfate-polyacrylamide gel electrophoresis for the separation of proteins in the range from 1 to 100 kDa. Analytical Biochemistry, November 1987, vol. 166, no. 2, p. 368-379.

TINCU, Andy J.; and TAYLOR, Steven W. Antimicrobial peptides from marine invertebrates. Antimicrobial Agents and Chemotherapy, October 2004, vol. 48, no. 10, p. 36453654 .

YEAMAN, Michael and YOUNT, Nannette. Mechanisms of antimicrobial peptide action and resistance. Pharmacological Reviews, March 2003, vol. 55, no.1, p. 27-55.

ZASLOFF, Michael. Antimicrobial peptides of multicellular organisms. Nature, January 2002, vol. 24, no. 415 , p. $389-395$. 